\title{
ASSESSING THE REGIONALITY DEGREE OF REGIONAL PRODUCTS OF THE USTÍ REGION (CZECHIA)
}

\author{
Vladan Hruška ${ }^{1}$, Lucie Broumová, Jan Píša
}

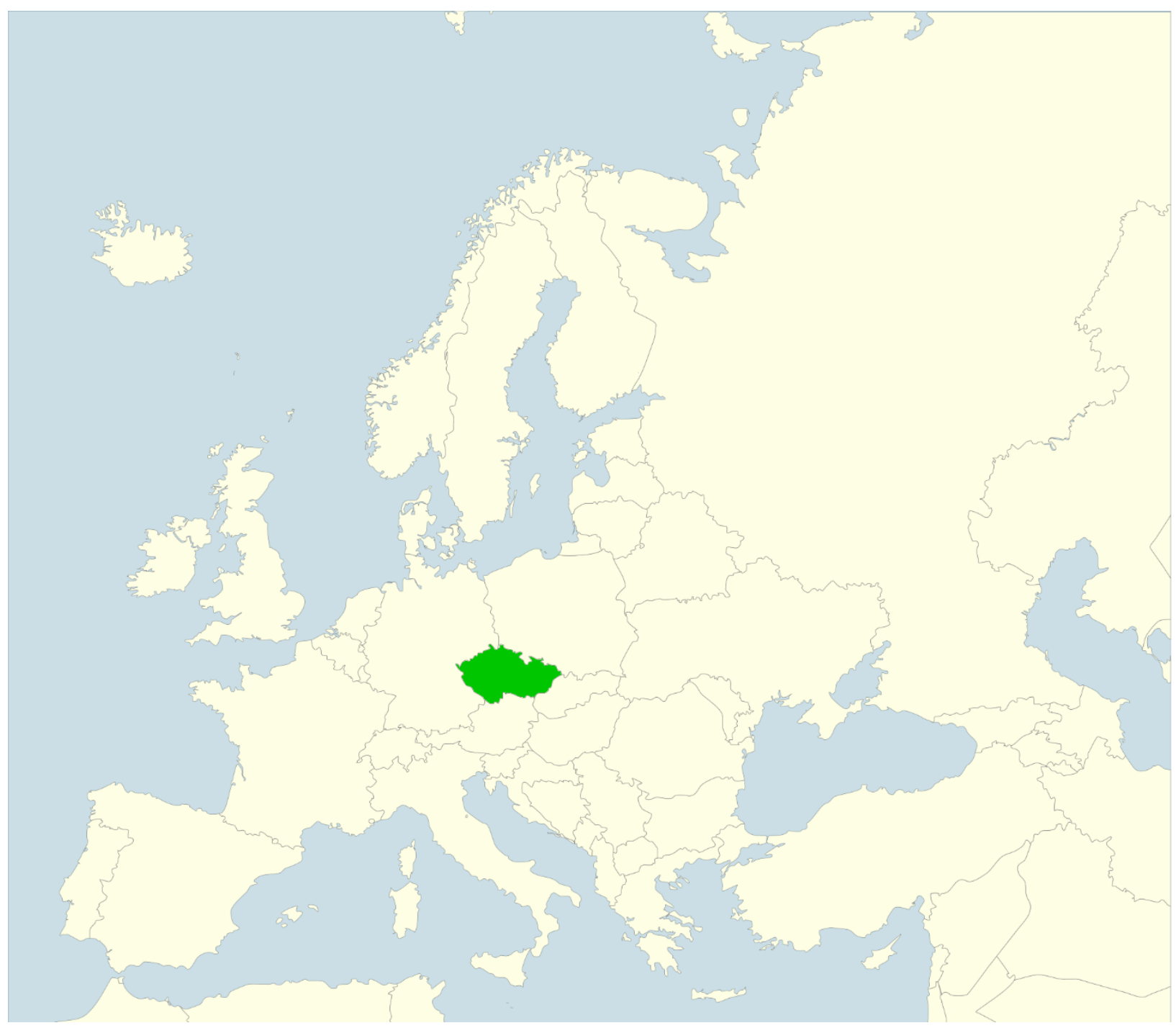

\footnotetext{
1 Mgr. Vladan Hruška, Ph.D., Department of Geography, Faculty of Science, Jan Evangelista Purkyně University České mládeže 8, 40096 Ústí nad Labem, Czechia, Email: vladan.hruska@ujep.cz
} 
Abstract: In Czechia, especially in the last decade, there has been an unusual expansion of regional labelling of products, experience, and services. This trend confirms the paradigmatic change in the approach to rural development, as well as the growing popularity of alternative food networks and forms of consumption. The boom of regional labelling, however, can threaten the future perspectives of regional products. Too many regional or supra-regional labels (and subsequently too many regional products) can reduce the presented uniqueness of these products and increase the danger of them becoming mainstream. The aim of this paper is to assess regional products' relational intensity to a particular region. For this purpose, a specific method for the assessment of regional products of the Ústí Region (Czechia) has been developed and applied. The resulting "regionality degree" should express the rate of traditionality of each regional product. Based on the application of this methodological approach, the paper confirms the concern of the expansion of regional labelling, even on those products whose embeddedness in the region is relatively weak. The reason for this might also be the specific economic history of the region influencing the degree of regionality of given products or, more precisely, their existence, to some extent.

Key words: regional products, regional labels, regionality, Ústí Region, Czechia

Abstrakt: $V$ Česku především v posledním desetiletí dochází k nebývalému rozmachu značení produktů, zážitků a služeb nejrůznějšími regionálními certifikáty. Celý tento trend potvrzuje paradigmatickou změnu v př́stupu k rozvoji venkovských regionů, a také rostoucí popularitu alternativních potravinových sítí. Výše zmíněný trend však má i svá negativa - jenom v Česku vznikla celá řada regionálních či nadregionálních značení a s tímto kvantitativním nárůstem pozvolna zaniká prezentovaná unikátnost jednotlivých produktů a dochází $\mathrm{k}$ jejich mainstreamingu. Cílem tohoto článku je posouzení intenzity vazby daného produktu $\mathrm{k}$ regionu a jeho tradicionalitu. Pro tento účel byla vyvinuta metodika pro hodnocení regionálních produktů Ústeckého kraje, jejíz výsledkem je index regionality vyjadřující míru tradicionality regionálního produktu. $\mathrm{Na}$ základě aplikace navržené metodiky článek potvrzuje obavy z rozšíření regionálního značení i na ty produkty, jejichž vazba k území je relativně slabá. Důvodem pro to může být i specifická ekonomická historie kraje, která do značné míry ovlivňuje míru regionality daných produktů, resp. jejich existenci.

Klíčová slova: regionální produkty, regionální značky, regionalita, Ústecký kraj, Česko

\section{Introduction}

Regional products, a term that one may hear more and more often, has been discussed a lot lately. The development of regional labelling (which should confirm "regional status" in particular), mostly food and handicraft products, has been in progress since the early 1990s in Europe and North America (Kašková, Chromý 2014). Gradually, such labelling developed on regional, national, and even international levels (see the protected designation of origin, protected geographical indication and traditional specialities guaranteed labels implemented by the European Union). This process both reflects and supports the growing popularity of regional products and, among other things, is also related to the paradigmatic shift in approaches to rural development. Today, the commodification of local resources (e.g., traditional food and handicraft products) is the key principle of development of rural localities and, therefore, stands in the centre of attention of the new rural development paradigm implemented by the EU (van der Ploeg et al. 2000, Woods 2011).

Speaking of food, such paradigmatic transformation is also supported by the expansion of alternative food networks. This concept reflects the increasing demand for food of local origin in developed countries since the 1990s or mid-2000s in Czechia (Renting et al. 2003; Spilková, 
Perlín 2013) ${ }^{2}$. Therefore, in the perception of regional planners and decision makers, regional products become a powerful tool for local economic growth (Pike 2015) which might also be used for attract tourists and visitors. From this point of view, regional products are part of marketing methods for economic valorisation of regional resources (Kašková, Kučera, Chromý 2016) and as such, they not only enhance the image of the region, but help him to (re-)locate in the globally integrated world (Groote, Huigen, Haartsen 2000).

On the other hand, constant introduction of new labelling systems and a growing number of products with regional labels can lead to jeopardising the purpose of regional labelling. A very large number of different regional labelling schemes leads to a kind of fetishization of products certified by a regional label (Spilková, Fialová 2016) and to customer confusion when selecting products (Kašková 2014). Hereby, the regional products are also losing their key advantage their positioning as social and economic alternatives to globalised production networks (Spilková, Fialová 2016).

The aim of this paper is to assess the degree of regionality or traditional relations of a regional product to the region of its origin. By this approach, the tendencies to inflation labelling can be unveiled and the mainstreaming of regional products could be prevented. In order to distinguish between products with strong relation to a particular region and products whose geographical embeddedness in the region is very low, a simple method has been introduced and applied on regional products in the Ústí Region in Czechia (therefore, the institutional background and also the system of regional labelling in the Ústí Region is analysed).

\section{Regional products and regional (rural) development}

\subsection{Regionality and authenticity of regional products}

The term regional product could be interpreted as a product related to a certain region. This relation between the product and region constitute the key deliberate component of its quality (Winter 2003 quoted in Kašková, Chromý 2014, 87) and, therefore, it is the main feature of such a product. This connection might be a spatial one, as well as a time one (the latter then determines a degree of production tradition in the region).

Concerning the former, there is no clear definition for the spatial term "regional" which then complicates the whole concept of regional labelling. As, for example, Kapferer (2002, quoted in Pike 2015, s. 69) argues that the "...idea of the 'local' brand, which does not specify what is meant by 'local' but attaches the label to everything other than (similarly undefined) 'global' brands." Thus, the question, "how should the term regional be defined?" should be asked and answered. One may assume a clear, particular connection to a specific region. It is not difficult to determine such a connection when agricultural raw materials, products, and food are considered. Such products have the best prerequisites to be labelled as regional due to their non-replicable, unique features given by their clear connection to a given location (Parrott et al. 2002). However, with the growing spatial distance of primary raw materials from their original locations, it is increasingly difficult to distinguish the degree of regionality of such a product.

If we consider the latter term "authenticity", actors of regional labelling try to draw our attention to a specific "commodity biography". Apart from guaranty of regional origin, such products should have a close relation to local traditions - to specific ways of doing things and thinking - typical for the region and livelihoods of local people or, more importantly, their ancestors. The longer a product is settled in this nest of relations, the more intensive its relation to the region is. A large proportion of handmade production (which also implies its small-scale production) and environmentally friendly production (Kašková 2010) is necessary for an "optimal" commodity biography. Like this, the product should evoke the idea that it is the result of craft production, domestic or independent craftsmen work, than a product of factory (mass) production. As such, regional products are part of rural idyll and as the rural idyll has more or less commercial character

\footnotetext{
2 It is interesting to note that in the mid 2000s or, more precisely, at about 2005-2008, according to Olšová and Jánská (2016), the construction of shopping centres in Czechia peaked. Does this also mark the peak of mass consumption behaviour in Czechia?
} 
(Short 2006), such a configuration of the commodity biography can help tremendously to make the product attractive and competitive in particular market conditions (Pike 2015).

Thus, regional products involve some regional characteristics that are given by natural conditions, cultural heritage, and traditions (Asociace regionálních značek 2016). In circumstances like these, if the product comes from a positively perceived region, it can significantly increase its exchange value because consumers associate the quality of the product with the quality of the region (Ilbery, Kneafsey 1999). Regional labels are then specific spatial collective property that (as opposed to privately owned trademarks), cannot be relocated. This label then provides producers with a certain form of protection against outer producers (Pike 2015).

\subsection{Roots of the boom of regional products}

The growing popularity of regional products relates to several factors. The key factors are modernisation of national economies and liberalisation of international trade (Pike 2015). These processes drive the global integration of world trade, both with industrial and food products (Woods 2009). Global integration then conditions:

- an environment for importing new values, ways of thinking, and shopping habits which might not prefer traditional local products (Woods 2009),

- a much more competitive environment (Bourguignon et al. 2008) where international companies have enormous power and influence prices to a considerable extent; this may lead to the dislodging of some traditional products (along with their producers) from the market (Woods 2005, 2009).

Full implementation of the Fordist system of production from the end of World War II until the early 1970s (Coe, Kelly, Yeung 2013, in socialist countries until the 1990s) and later global economic integration led to the development of mass production and consumption (Mackinnon, Cumbers 2007), expansion of economies of scale and ever-increasing product standardisation. The character of such standardisation is then very often determined by several large companies, which try to emphasize the superiority of their products over other products. As a result, "local consumer preferences for local producers" are suspended (Pike 2015, s. 4).

Similar development can be observed in agriculture as well. Agricultural modernization preconditioned industrialization of agricultural production and, simultaneously, the shift from selfprovisioning agriculture to commercial, and increasingly globally integrated one (llbery, Bowler 1998: 62-64). Such processes are typical for both capitalist and post-socialist European agriculture whose character and nature are driven by the Common Agricultural Policy (CAP) of the EU (Gray 2000) today. Constant pressure on productivity, quantity, and price of agricultural production significantly affects the quality of food produced in conventional farming. Such processes then evoke growing consumer mistrust in conventionally produced food. Moreover, they are further fuelled by the increasing number of food scandals since the 1970s or are in fear of genetically modified organisms (Renting et al. 2003, 395). As a result, consumers are increasingly refusing "placeless and faceless" food produced from conventional agriculture (Goodman and Goodman 2009, s. 209) and, thus, space opens up for new forms of production and food chains which guarantee considerable trust between consumers and suppliers. Maximally, such new organizational ways shorten the physical and psychological distance between the producer and consumer (Allen and Hinrichs 2007), and are conceptualised as alternative food networks (or short food supply chains) (Goodman and Goodman 2009).

It seems that Schermen's thesis (2015, quoted in Chalupová, Prokop, Rojík 2016, p. 110) that there is a shift in the food system from 'food from elsewhere' to 'food from here' is increasingly relevant in Czechia. The same could also be applied to handicraft products labelled as "regional". Both food and handicraft products gradually infiltrate the market regulated by the conditions of severe competition and standardisation on a global level. Such conditions of mass market, however, create a favourable environment for uniqueness and authenticity. Increasing economic regionalism or localism ("buy local") or nationalism ("buy Czech") stimulate a demand for authenticity (Pike 2015) which can be offered just by non-standardised products with clear and close origin. This kind of demand gives an opportunity to producers who might not compete with 
large agricultural or manufacturing companies in terms of quantity, but in terms of quality, focusing on a particular market niche.

\subsection{Regional products and their benefits for the region}

As Bauman (2007, quoted in Pike 2015, p. 6) points out, we live in a time of "consumer-dominated economy, society, culture, ecology and polity... [when - added by authors] the brands and branding of goods and services, commodities have risen to prominence in a dramatic fashion". Such consumer behaviour influences functional transformation of rural areas of developed countries, which are losing their production function (retreat of productivist agriculture) at the expense of consumption function (growing tourism and residential functions of rural localities) (e.g., Woods 2005; Holmes 2006; McCarthy 2008; Mackay, Perkins, Espiner 2009; Hruška, Konečný 2014).

Following transforming functions of rural area, change in basic paradigms of rural development occurred. The modernization development paradigm has been replaced by a new rural development paradigm (van der Ploeg et al. 2000) implemented in the EU within the CAP. Woods (2011) defined three key elements of the paradigm - endogenous development, spatially integrated development, and bottom-up development approaches. Due to the character of this paper, only the endogenous development element will be discussed in the following paragraphs.

Endogenous development is based on the activation of local stakeholders who should sustainably valorise local resources of tangible (immovable cultural assets, landscape) and intangible nature (local food, crafts, folklore). Local people should make a local resources audit (Moseley 2003), evaluate their commodification potential, and then apply territorial valorisation strategies (Ray 1998) in order to add value and bring wealth and new job opportunities to the region (Moseley 2003). These new job opportunities should substitute those lost during the productivist period of agricultural production. From this point of view, (coulinary) tourism is perceived as a promising tool for generating new employment opportunities in rural areas due to its labour-intensive nature (Hall, Gössling 2016).

Commodification of local resources can help to build a positive regional image, and increase resistance of such a region to globalization pressures erasing cultural differences among regions (Paasi 2003). From this point of view, regional labelling is perceived as one of the tools shaping the regional image. It helps to differentiate space and stress cultural specificity of particular regions (Messely 2009). This might be very helpful as each region competes with other regions for limited resources - "new and existing businesses, investments, jobs, occupations, residents, skilled labour, spectacular events, students and visitors" (Pike 2015, p. 175; similarly, also Groote, Huigen, Haartsen 2000; Hruška, Konečný 2014 etc.). On the other hand, regions that do not shape their own image actively risk being invisible, ignored, or lagging behind (Pike 2015, p. 175). Image-shaping activities are especially important in regions that are perceived negatively, for example, due to polluted environments or unsuccessful economic transformation.

The second pillar of stimulation of rural economies is accepting the principles of economic relocalization (e.g., Moseley 2003; Johanisová 2004; Fraňková 2012; Copus, Hopkins, Creaney 2016). Local stakeholders should take suitable measures which help to "plug holes in the bucket" of local economies (Moseley 2003,28) through which the capital leaks out to globalised markets (Copus, Hopkins, Creaney 2016), or to support more intensive capital circulation (Johanisová 2004). Institutional and financial support for marketing of regional farming and handicraft production by regional labels is another typical example of relocalization activities. Such marketing strategies integrate regional products in extra-local networks that are a crucial part of Ray's (2006) reconceptualization of endogenous development called neo-endogenous development. Like this, regional labels help to attract tourism-related capital to rural areas (WTO, ETC 2009). Such strategies of tourism development are very often built on specialised (branded) food products transformed in a rural experience such as rural tours, direct on-farm purchasing, specialised restaurant menus with an emphasis on local food, etc. (Hall 2006). 


\section{Regional products and their support in the Ústí Region}

\section{1 Ústí Region - from the mediator of innovations to the old industrial region}

Ústí Region is a self-governing region in North-West Czechia having a common border with the Free State of Saxony, Germany. Ústí Region was traditionally oriented towards the mining industry; since the middle ages, there has been raw-material extraction in the Ore Mountains and Most Basin. Before the industrial revolution started in Czechia, craft production developed in the textile industry (from the 1780s in the Děčín and Šluknov areas; Kárníková 1965) and later in the glass industry (Anděl 2000). The spatial proximity of the Ústí Region to one of the cores of the industrial revolution on the European continent (German Saxony) launched its considerable economic growth from the 1870s. Industrial revolution spread from Saxony across the Ústí Region further to Czechia (Koutský 2011) because the region had good preconditions for such innovation transfer. The textile and glass industries - initiators of industrial revolution - were developed there (Purš 1980, Mareš 11080 quoted v Koutský 2011, p. 59), as well as lignite reserves, good railway connections, and inland waterways on the Elbe river (Koutský 2011). Therefore, in 1930, the Ústí Region was one of the most industrialized regions in Czechia measured by the number of people working in manufacturing.

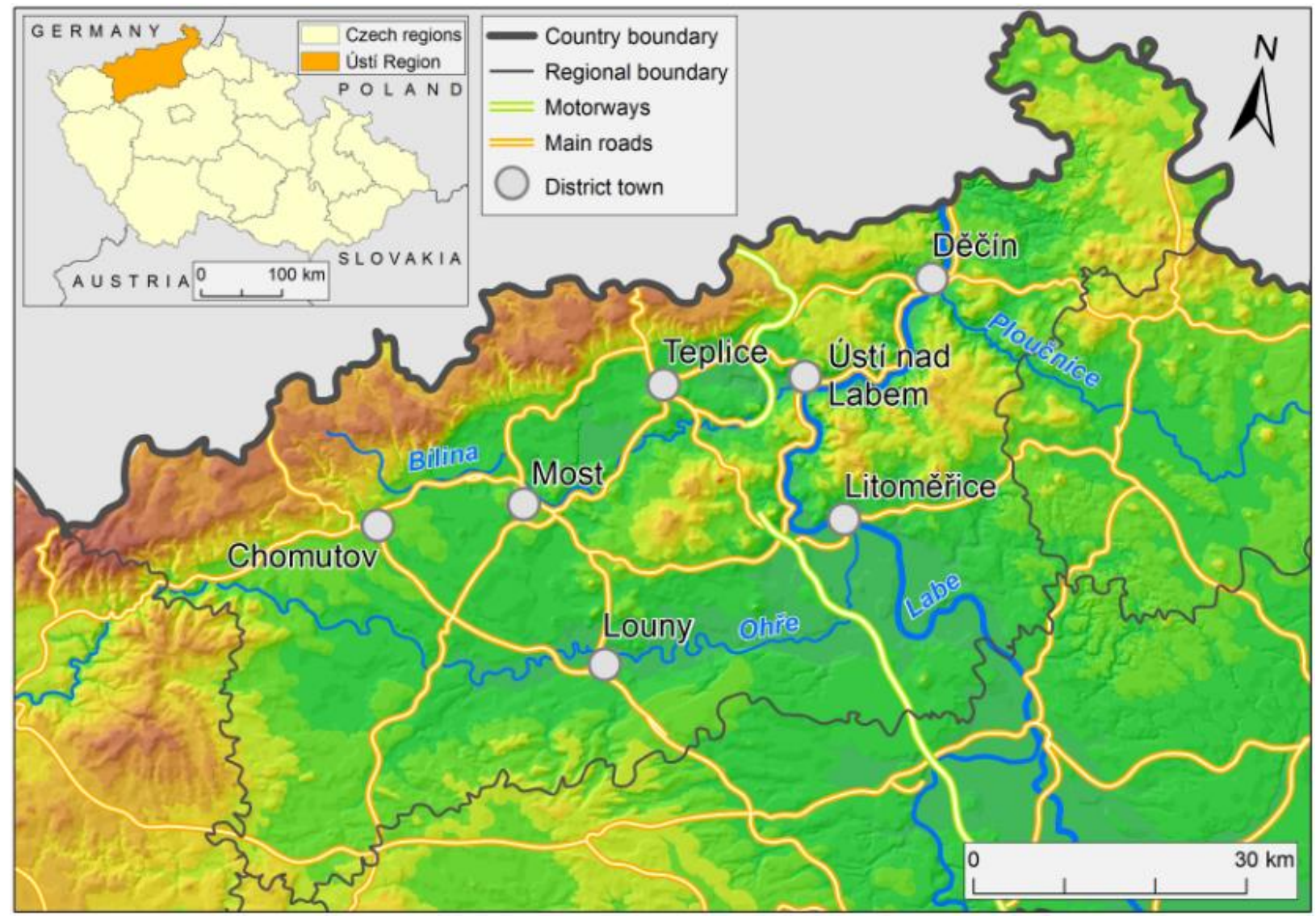

Fig 1. Map of the Ústí Region and its location. Source: authors

In the 1930s, economy of the Ore Mountains, manufacturing industries related to contemporary regional products were particularly focused on the wood processing industry (including toys production). Basketwork and knitted goods, except for furniture, were located in the Šluknov and Litoměrice region; the textile industry concentrated at the state border with Germany, specifically in Varnsdorf, near Teplice, Vejprty, and Litvínov. The ceramic industry was also considerably widespread (especially around the town of Dubí), as well as porcelain production (again, mainly around the towns of Dubí and Teplice) and the glass industry (Teplice and the Děčín region). Regarding the food industry, dairy products prevailed, as well as wine and beer production. At that time, breweries were evenly distributed throughout the whole region. Vineyards spread in 
agricultural areas with a warmer climate in the Litoměřice region, commercial fruit and vegetable growing was localised here as well (Atlas of the Czechoslovak Republic 1935).

Relatively successful economic development of the region until the end of the 1950s was interrupted by two key events in the post-war period. Firstly, the transfer of Germans (in 1945 and 1946) who, until 1946, made up the majority of the regional population and caused almost complete replacement of the workforce for many companies. Moreover, this act broke the intergenerational continuity in knowledge-sharing and experience transfer and, together with the geographical reorientation of trade activities towards the COMECON countries, regional enterprises were unplugged from their counterparts in Western Germany. In this regard, the glass, textile, and wood-processing industry experienced the highest decline (Koutský 2011). Secondly, the socialistic transformation of the economy from 1948 erased small businesses, put an emphasis on heavy industry for which the region had optimal preconditions (extensive lignite deposits), and promoted development of the Fordist mode of production in large state-owned companies. During the socialist period, importance of industries typical for the first stage of industrial revolution (textile, glass industries) measured by their contribution to regional employment was decreasing at the expense of heavy industry (Koutský 2011). Strong state support for these industries continued, more or less, until the end of the 1980s, and a technological lock-in was established, which formed the basis for social and economic problems related to the post-socialistic economic transformation of the region.

The fall of the communist regime in Czechia (1989) created space for neo-liberalisation of regional economy and society. Inflexible Fordist socialist companies had to adapt to new market conditions. From this point of view, the inherited economic orientation of the Ústí Region on heavy industry appeared as very unfavourable and unsustainable. As a result, unsuccessful economic transformation unemployment has increased rapidly, thus, now it has the highest unemployment rate $(6.3 \%$ against the state $4.1 \%$ in July 2017, MPSV 2017) in comparison with other Czech regions. Other problems typical for old industrial regions occur as well - low life expectancy, high death rate, and brain drain, resulting in a low proportion of people with university degrees (Čsú 2014a) and socially excluded localities. Overall, the accumulation of these problems creates an image of the Ústí Region as a region with a devastated environment and social problems (Kučera et al. 2014, Kučerová et al. 2016).

\subsection{Regional products in the Ústí Region as a tool for regional economic growth}

Labelling of regional products started to develop in Czechia at the beginning of the new millennium. In 2014, there were approximately 50 systems for labelling regional products (Kašková 2014). For example, Chalupová, Prokop, and Rojík (2016) dealt with labelling national and regional products in Czechia in greater detail; therefore, this chapter will focus only on the promotion of regional products initiated by institutions based in the Ústí Region.

On the regional level (Ústí Region), regional labelling proceeds via a competition called Food product of the Ústí Region - the region of Přemysl Oráč ${ }^{3}$ since 2008. The competition was set up by the Regional Authority of the Ústí Region, together with the Agrarian Chamber of the Most and Teplice district, the Regional Information Centre for Agricultural and Rural Development, the Regional Agrarian Chamber, and the State Agricultural Intervention Fund. The label is awarded to food or agricultural products that meet selected criteria, i.e., if the product comes from the region and is $100 \%$ made in the Ústí Region, and shows unique regional qualities. The competition was organizationally united with the nation-wide competition Regional food in 2016. Both labels use the same criteria for product evaluation (apart from quality, the label should guarantee the regional origin of the product and promise original taste; Klánová 2013), nevertheless, both are awarded separately.

In 2004, a non-profit organisation Asociace regionálních značek (ARZ - Association of Regional Brands) was established in Czechia. This association coordinates the system of product, service, and experience labelling at the national level. Currently, the Association has joined 26 regions with their own labels. While the first regional label under this association was created in 2004, in

\footnotetext{
3 Přemysl Oráč - Přemysl the Ploughman is a mythical person of Czech legends who lived in the Ústí Region.
} 
the Ústí Region, the first label was introduced much later in 2010. Today, there are four regional labels created on the micro-regional level within the Ústí Region - the Českosaské Švýcarsko regional product ${ }^{\circledR}$ (Bohemian-Saxon Switzerland regional product, since 2010), the Krušnohoři regional product ${ }^{\circledR}$ (Ore Mountains regional product, since 2013), the České středohoří regional product $^{\circledR}$ (Central Bohemian Uplands regional product), and Poohří regional product ${ }^{\circledR}$ (Ohře riverbasin regional product, both since 2015).

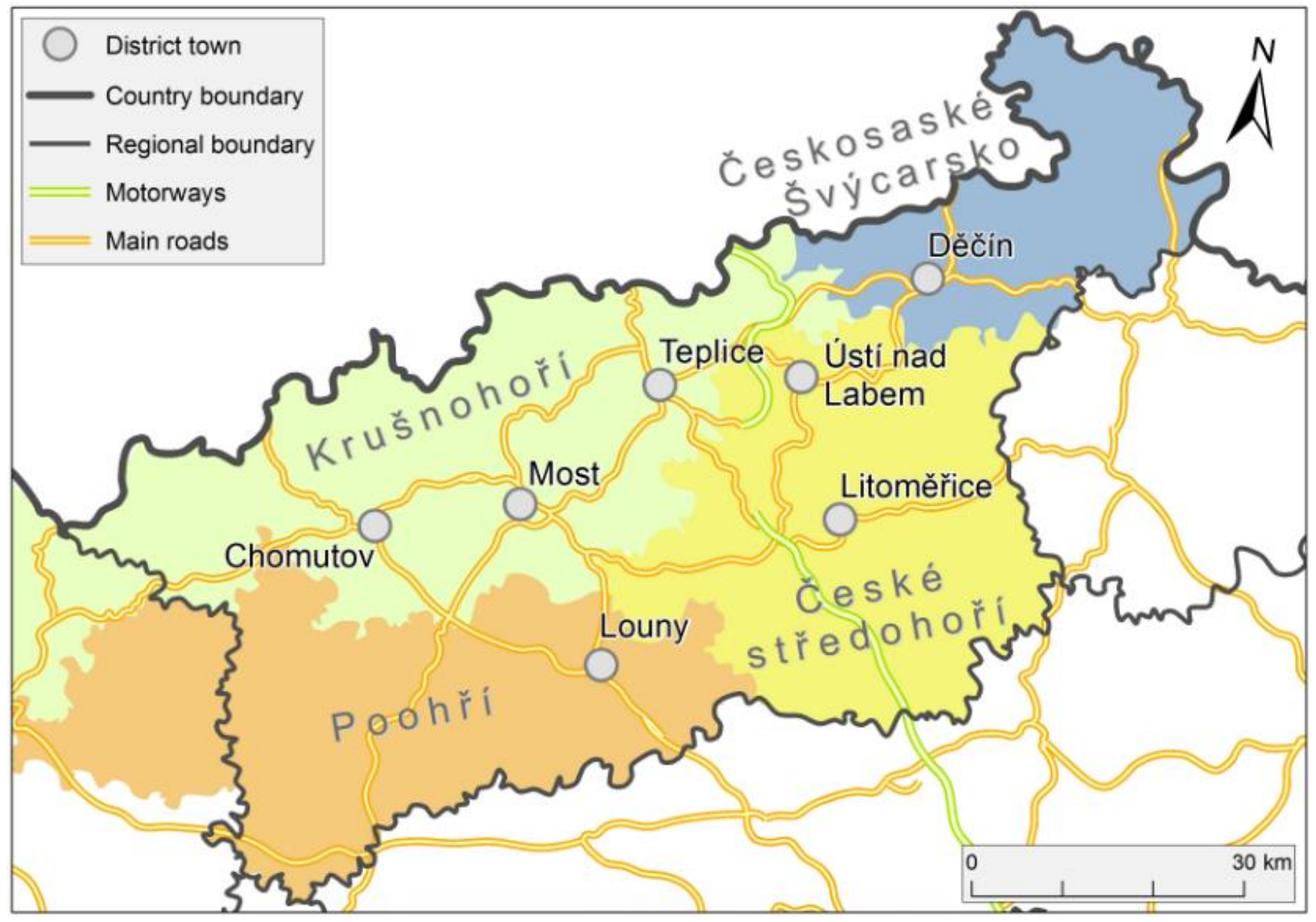

Fig 2. Map of areas of regional labelling in the Ústí Region. Source: authors based on the ARZ

The establishment of the first two labels - the Českosaské Švýcarsko regional product ${ }^{\circledR}$ and the Krušnohorí regional product ${ }^{\circledR}$ - was rather a bottom-up initiative. The initiator of the establishment of the former label was the non-governmental organisation České Švýcarsko o.p.s. (Bohemian Switzerland). This organisation was established in order to develop sustainable tourism in the National Park České Švýcarsko in 2001 by the National Park Administration, the municipality of Krásná Lípa, and the Czech Union for Nature Conservation Tilia. Concerning the latter case, the initiator of the regional label was the Local Action Group Sdružení Západní Krušnohoři (Association Western Ore Mountains). The other two regional labels representing less attractive areas for tourism were established by Destination Agency for České Středohoří (Central Bohemian Uplands) and the Destination Agency for the Dolní Poohři (lower Ohře riverbasin). Both agencies were founded by the Ústí Region Regional Authority in order to support the tourism development in their areas. From this point of view, introduction of these regional labels was rather a top-down initiative. Currently, the area of all four labels completely covers the area of the region (see Fig. 2).

According to the ARZ website, the purpose of the labels is to support local firms. Sales of these products should be supported both by local people who support "their local" producer or neighbour, and by tourists who prefer purchasing "real and quality regional souvenirs". However, the Poohrí and České středohoří regions - regions profiting less from tourism - stress the creation of a positive image of the region; more precisely, the purpose of regional labels is to "make the region visible" (Association of Regional Brands 2016). 
Importantly, it is necessary to mention "The Catalogue of Handicrafts in the Ústí Region" as a tool for the support of regional products. This catalogue was created by the Regional Authority of the Ústí Region. The first edition was published in 2014 (since then, there have been two updated and extended editions) and it comprised of 57 craftsmen and farmers in total. The declared purpose of the Catalogue is to "sustain craft traditions and support the sales of small businesses and craftsmen". Printed catalogues were distributed to municipal authorities, information centres, and regional companies and institutions as well. In the latter case, the Catalogue was supposed to encourage these actors to buy craft products as souvenirs and presents for their partners. The electronic version of the Catalogue is available on the tourist information website Brána do Čech (Gate to Bohemia) and on the website of the Ústí Region. For more details about the Catalogue, see the Methodology section.

As previously stated, the continuous introducing of new systems of labelling in the Czech Republic and the Ústí Region might lead to jeopardising the purpose of regional labelling. Too high a number of regional labelling systems leads to consumers' confusion because they might not be able to see differences among individual labels and, more seriously, the uniqueness of the particular regional product. Therefore, there is a danger of mainstreaming of regional products.

\section{Methodology for assessment of the regionality degree}

In order to assess and further prevent the mainstreaming danger, the authors suggest a methodology for evaluating the regionality degree of a given product. Such methodology could thus distinguish among products with stronger or weaker connections to the region and therefore potentially decide whether the given product should be labelled with the regional label or not.

The first 2014 edition of "The Catalogue of Handicrafts in the Ústí Region" (referred to as the "Catalogue" from now on) was used to verify the methodology for the evaluation of regional products. This source has been selected for its wide range of products and it contains both food and craft products with or without a regional label. As mentioned above, the main purpose of the Catalogue is to support small craftsmen and farmers. Therefore, it was not necessary to achieve a certain level of traditionality and authenticity in order to be included in it. However, the key criteria for a producer to be included in the Catalogue was to be based in the region, have a high ratio of hand-made production, and a "non-mass" nature of their products. Many presented craftsmen and farmers have been awarded with one of the four regional system of labelling in the Ústí Region discussed above.

Regarding the evaluation of the degree of regionality of a given product itself, a scoring method has been chosen. The scoring criteria are similar, to a certain extent, to the criteria used in labelling systems for the product labelling. However, the difference with this method is that it stresses the relation to the region more precisely. The result of the scoring does not determine whether the product met the criteria or not, but defines rate of relations of the given product to the present and historical constellations of the region in comparison with other products. The following three key criteria construct the "regionality degree" index. Each product could receive a total of 11 points if meeting all the criteria:

1. Origin of the raw materials used for the product;

2. Product's relation to the traditional manufacturing industries of the given locality geographical embeddedness; and

3. Duration of continuous production.

Ad 1 - Regional origin of raw materials and its attachment to the regional organic and inorganic environment is one of the crucial factors for defining regional products. To operationalize this argument, products mostly using raw materials from the Ústí Region (or the neighbouring region if the producer resides on the borders of the Ústí Region) received 4 points. In some cases, producers used recycled waste materials for the production process. In this case, its origin is considered as local and therefore scored 4 points as well. Products using raw materials from other Czech regions scored 2 points, and products using raw materials mostly from abroad scored 0 points. Data for this criterion was collected directly by contacting the producer, either by phone 
or by email. In some cases, it was not possible to obtain the producer's response so the product was excluded from the assessment.

The other two criteria describe the tradition of a given regional product, both from spatial and time approach.

Ad 2 - Regionality of a particular product is very often given by the regional image. If the region is clearly (and positively) associated with a particular manufacturing activity, then it significantly supports the image (and marketing) of such product and increases its exchange value (e.g., sparkling wine from Champagne). Therefore, the more tighter the relation is between the product and the corresponding region, the more traditional this product appears. Based on these assumptions, products whose manufacturing tradition is directly connected to the producer's seat (the same municipality) or even to the same building or producing premises, scored 4 points. Products whose manufacturer has a tradition in the administration district of the municipality with extended competencies (obce s rozšírenou pưsobností - spatial units delimited for purposes of state administration, approximately commuting-to-work areas, referred to as the "microregion" from now on) scored 3 points, while products based on traditional economic industries typical for the whole Ústí Region scored 2 points. Product with a minimal connection to the Ústí Region scored 0 points. As the time-spatial basis for the assessment of the relation intensity of the given product to the region, spatial concentration of relevant industries in the Ústí Region in the 1930s has been considered. For these purposes, the Atlas of the Czechoslovak Republic (Česká akademie věd a umění 1935, for an example see Fig. 3) was used. The reasons why this source was selected is that (1) it shows the economic situation in the Ústí Region before the Fordist system of mass production was fully implemented in the region, and (2) it describes the economic situation before the German-speaking inhabitants were expelled taking (not only) their production traditions and knowledge with them.

Ad 3 - The duration of a particular manufacturing activity in the region also forms its, and the product's, image. The longer it is, the more intensive is the penetration of the regional image (hereby, we are coming back again to the criterion 2). Moreover, long product's history (tradition) gives the product a sense of authenticity because such kind of production in "the good old days" is so deeply present in idyllic rural perceptions. The criterion might be perceived as being discriminative, which means excluding those products whose production tradition is very short, despite the positive character of the product (in terms of its relation to traditional economic industries). However, it should serve rather as an informative tool in order to assess the relation of such product to the region where the duration of the production plays a crucial role. From this point of view, products that have been continuously produced for more than 69 years scored 3 points. Their traditions go back to the pre-socialist period and they have "survived" both the expulsion of the German-speaking population and the pressure of socialistic centralization and modernization of industrial production. Products whose traditions began in the period of socialism (i.e., 28-69 years of tradition) scored 2 points. Products with shorter tradition from the "new" capitalism era (since the end of 1989, 10-27 years of tradition) scored 1 point. Younger products (0-9 years) scored 0 points. The criterion does not reflect on the change of the firm's name or legal form or some minor product alterations during the time. Information needed for assessment was surveyed from the websites of individual producers. In case they were not available, the producer was asked by phone or email. In some cases, it was not possible to obtain the producer's response; therefore, the product was excluded from the assessment. 


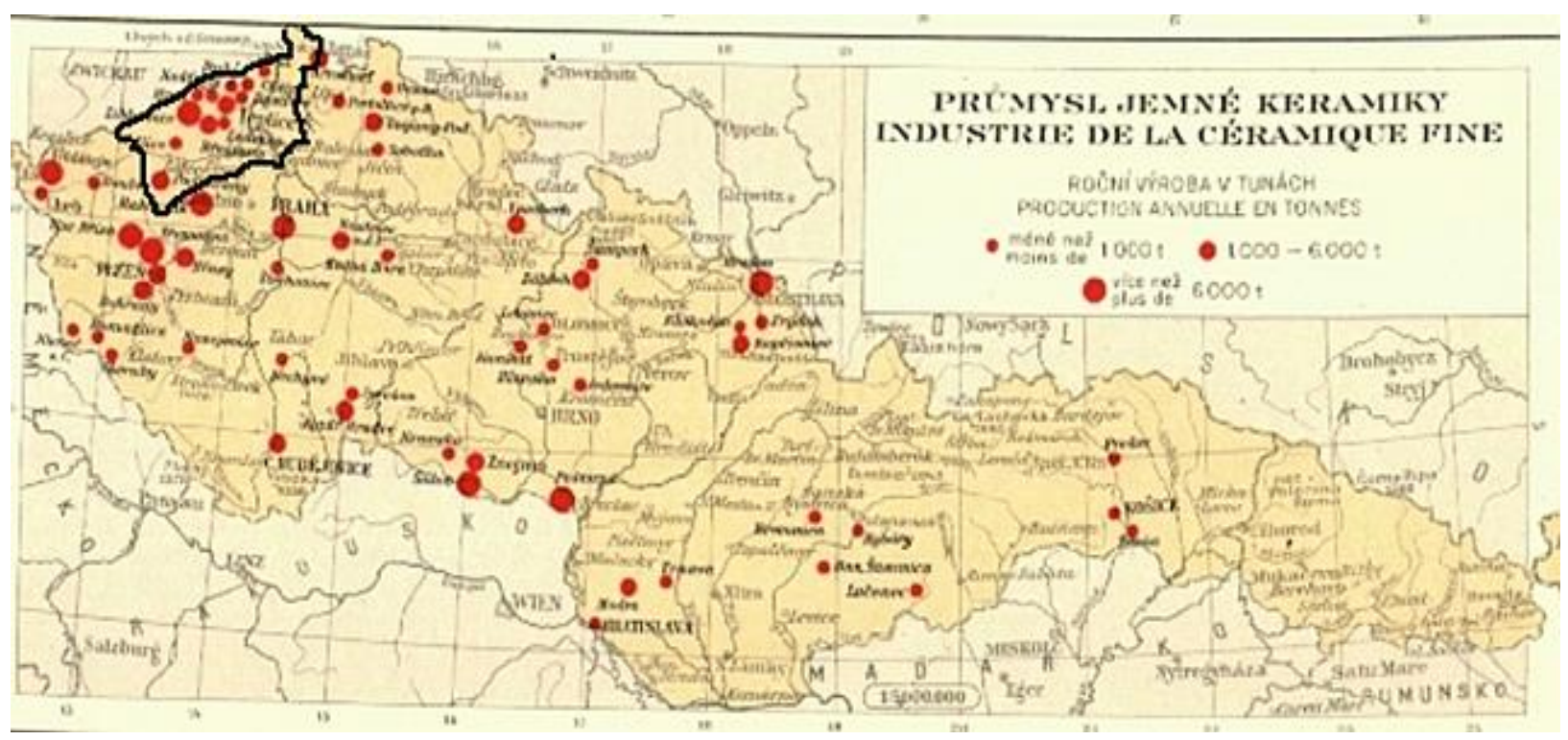

Fig 3. Example of a map from the Atlas of the Czechoslovak Republic demonstrating the spatial distribution of the light ceramic industry in Czechoslovakia in 1930. Source: Česká akademie věd a uměni (1935); boundaries of the UUstí Region added by authors

\section{Results of the regionality degree assessment}

Based on the described methodology, 43 products from a total of 57 craftsmen listed in the Catalogue were evaluated (14 craftsmen did not submit information for one or two criteria of assessment). The assessment of five best and eight worst evaluated products is summarized in the following table. To guarantee the producers' anonymity (often natural person) the table below lists only the names of products.

Only one of the products reached the perfect regionality degree (11 points): wooden decorations of a company located in the Krušné hory Mts. where the wood-processing industry (and also wooden toys and Christmas decorations production) was historically very significant. This company follows this strong tradition, despite its radical reduction since the end of WWII, and it almost disappeared from the Czech side of the mountains due to the expulsion of Germans. Today, this company is the only sole producer of that kind, whereas on the Saxon side of the Krušné hory Mts. there are still many. The producer resides in the same factory where this kind of production has been developed since 1889. From this point of view, labelling this product by the regional label Krušnohoří regional product $\circledast$ appears really legitimate.

Among other products with high degree of regionality is porcelain from the town of Dubí. However, key raw materials (china clay) for its production are imported from different regions of Czechia. Therefore, this product scored 2 points less than the previously mentioned producer. Nevertheless, regarding its production tradition, the company has been manufacturing in the same location since 1885 and is the oldest one in the database of producers.

Wooden furniture of a craftsman residing at the foothills of the Krušné hory Mts. scored the same result -9 points (his manufacture tradition is much shorter compared with the previous producers). Goat cheese, similarly as honey, from a farm (beekeeper) located near the NP Bohemian Switzerland is processed from goat milk produced directly on the farm, thus, the connection to the region is very strong, as well as the tradition of agriculture (beekeeping) in the countryside in general. Both products were labelled with the regional label Českosaské Švýcarsko regional product $^{\circledR}$. 
Tab 1. Five evaluated products with the highest and eight with the lowest degree of regionality. Source: Broumová 2015, Catalogue of handicraft of the Ústí Region 2014.

\begin{tabular}{|c|c|c|c|c|c|}
\hline Product & $\begin{array}{l}\text { Origin of } \\
\text { raw } \\
\text { materials } \\
\text { (points) }\end{array}$ & $\begin{array}{l}\text { Geographical } \\
\text { embedded-ness } \\
\text { (points) }\end{array}$ & $\begin{array}{l}\text { Duration of } \\
\text { production in } \\
\text { years (points) }\end{array}$ & $\begin{array}{l}\text { Rate of } \\
\text { regionality } \\
\text { (points) }\end{array}$ & $\begin{array}{l}\text { Label } \\
\text { (in 2016) }\end{array}$ \\
\hline $\begin{array}{l}\text { Wooden } \\
\text { decorations }\end{array}$ & Regional (4) & Place (4) & $127(3)$ & $\begin{array}{l}\text { Very high } \\
\quad(11)\end{array}$ & $\begin{array}{c}\text { Krušnohoří } \\
\text { regionální produkt }{ }^{\circ}\end{array}$ \\
\hline $\begin{array}{l}\text { Porcelain } \\
\text { products }\end{array}$ & Czechia (2) & Place (4) & $131(3)$ & $\begin{array}{l}\text { High } \\
(9)\end{array}$ & No \\
\hline $\begin{array}{l}\text { Wooden } \\
\text { furniture }\end{array}$ & Regional (4) & Micro-region (3) & $29(2)$ & $\begin{array}{l}\text { High } \\
(9)\end{array}$ & No \\
\hline Goat cheese & Regional (4) & Place (4) & $23(1)$ & $\begin{array}{l}\text { High } \\
(9)\end{array}$ & $\begin{array}{c}\text { Českosaské } \\
\text { Švýcarsko regionální } \\
\text { produkt } \circledast\end{array}$ \\
\hline Honey & Regional (4) & Place (4) & $24(1)$ & $\begin{array}{l}\text { High } \\
(9)\end{array}$ & $\begin{array}{c}\text { Českosaské } \\
\text { Švýcarsko regionální } \\
\text { produkt } ₫\end{array}$ \\
\hline \multicolumn{6}{|c|}{$\ldots$ other 30 products with rate of regionality reaching from 8 to 5 points $\ldots$} \\
\hline $\begin{array}{l}\text { Leather } \\
\text { accessories }\end{array}$ & Czechia (2) & Region (2) & $3(0)$ & Low (4) & --- \\
\hline $\begin{array}{l}\text { Natural } \\
\text { cosmetics }\end{array}$ & Czechia (2) & Region (2) & $9(0)$ & Low (4) & $\begin{array}{c}\text { Českosaské } \\
\text { Švýcarsko regionální } \\
\text { produkt } ₫\end{array}$ \\
\hline $\begin{array}{l}\text { Polygraphic } \\
\text { products }\end{array}$ & Czechia (2) & No $(0)$ & $31(2)$ & Low (4) & $\begin{array}{c}\text { Poohří regionální } \\
\text { produkt } \circledast\end{array}$ \\
\hline $\begin{array}{l}\text { Paintings, } \\
\text { sculptures }\end{array}$ & Czechia (2) & No $(0)$ & $27(1)$ & Low (3) & --- \\
\hline Gingerbread & Czechia (2) & No $(0)$ & $26(1)$ & Low (3) & $\begin{array}{c}\text { Krušnohoří } \\
\text { regionální produkt } \circledast\end{array}$ \\
\hline Pasta & Czechia (2) & No $(0)$ & $24(1)$ & Low (3) & No \\
\hline $\begin{array}{l}\text { Hand-made } \\
\text { paper }\end{array}$ & Czechia (2) & No $(0)$ & $13(1)$ & Low (3) & $\begin{array}{l}\text { České středohoří } \\
\text { regionální produkt }{ }^{\circledR}\end{array}$ \\
\hline $\begin{array}{l}\text { Stained } \\
\text { glass }\end{array}$ & $\begin{array}{c}\text { From abroad } \\
\text { (0) }\end{array}$ & Region (2) & $21(1)$ & Low (3) & $\begin{array}{l}\text { Poohří regionální } \\
\text { produkt } \circledast\end{array}$ \\
\hline
\end{tabular}

Pasta, hand-made paper, stained-glass, gingerbread, paintings and sculptures scored at the opposite end of the ranking system. What they have in common is a short tradition of production so far (the companies were established in the "new" capitalist period). They have a weak historical connection to the location or region (except for stained-glass) and raw materials for production do not come from the region. Leather accessories and natural cosmetics are more intensively embedded in the region despite the 1990s economic transformation, which significantly affected formerly very important leather manufacturing and chemical industries in the region. 
A general view of the whole set of the researched products (see Fig. 4) suggests that an average degree of regionality had the value of 6.3 and the median value was 7 . There were no products in the researched set whose degree of regionality was zero or very low. However, there are not many products with a high degree of regionality (only 13 out of the total 43 assessed products). On the other hand, products with a medium degree of regionality (22) comprised more than a half of the surveyed set (see fig. 4).

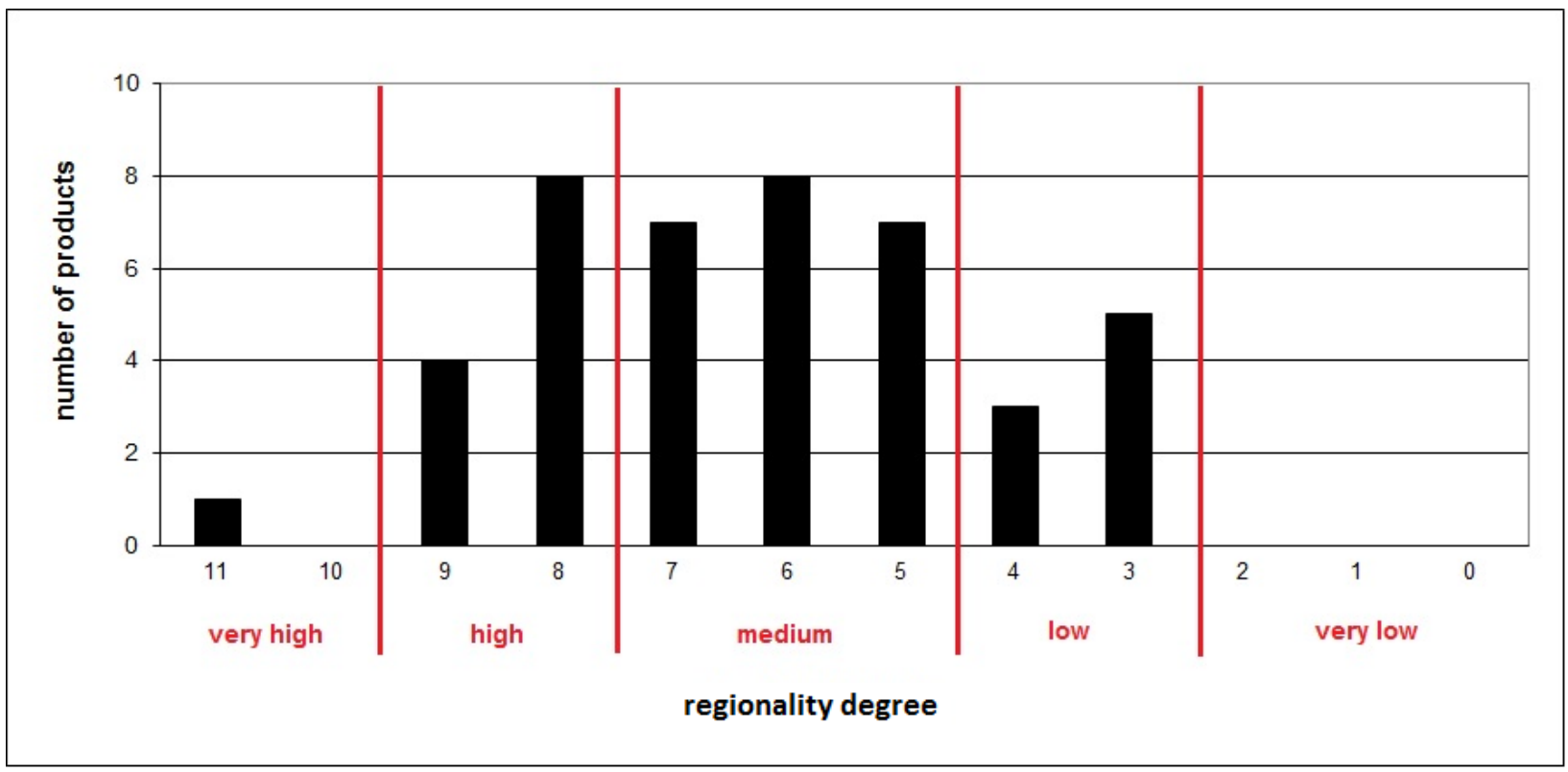

Fig 4. Number of regional products according to the value of their regionality degree. Source: Own research based on Broumová 2015

The diversity of the assessed products also allows for comparing the "strictness" of four labelling committees assigning regional labels. The Krušnohoří regional product ${ }^{\circledR}$ label performed the best, with six products scoring 7 points on average in the evaluated set. Českosaské Švýcarsko regional product ${ }^{\circledR}$ (12 products in total) received a little less (6.8 points). Three products with the České středohoři regional product ${ }^{\circledR}$ label were below average (average score 6.0 points - low number of assessed products must be considered), and Poohrí regional product ${ }^{\circledR}$ (six products with a mark of 5.7 points). The remaining 16 products, which were not labelled with any of these labels, received the average regionality degree -5.9 points. Food products produced directly on a farm reached a higher degree of regionality (average regionality degree 8.4 in comparison with 6.0 of other products), which confirms the thesis of Parrott et al. (2002) who spoke about a clear geographical connection of agricultural products to a given region.

\section{Discussion and conclusion}

The Ústí Regional authority has implemented and supported the strategy of promotional regional products, as well as many other regions in Czechia and abroad. In the same way as it appears in the literature (e.g., see Kašková 2014, Pike 2015), the motive for such action was mainly the support of regional economy and tourism development. Regarding the latter, regional labelling is used as a tool for commodification of new tourist destinations (especially the areas of Poohři and the České středohoři).

The activity of regional institutions in the field of regional labelling started in 2008 with the label food product of the Ústí Region (the region of Přemysl Oráč) initially as a promotion of regional farm producers. On the micro-regional level, there are four regional labelling systems covering the whole region. The conditions and key actors of their founding, despite common labelling instructions, were different. On the one hand, they originate in the bottom-up local initiative and it is declared that they should mainly support local producers and valorisation of local resources. On the other hand, their establishment was supported by the initiative from above (Ústí Regional Authority) in order to support tourism in areas so far less popular for visitors. Also, regional 
labelling in the Ústí Region evidence some marks of "overbranding" similarly as it is on the national level (Kašková 2014). In this regard, a certain indication of this might be the organizational unification of awarding two different labels: Food product of the Ústí Region (national level labelling) and Regional product of the Ústí Region - the region of Přemysl Oráč (regional level labelling) since 2016.

Spilková and Fialová (2016) argued that it is difficult to define and conceptualize the "quality" of regional products. At least in terms of their regional character, this statement appears to be true, as very variable values of the regionality degree of assessed regional products showed. Based on the suggested methodology, the results of the assessment imply that there are 13 products with a high regionality degree, 22 products with a medium, and eight products with a low regionality degree. Researched set of products did not show any significant differences between both labelled and non-labelled products and different labelling authorities. However, a slightly better score, on average, reached labelled products and especially those labelled by authorities whose establishment was driven by bottom-up.

Considering eight products with low regionality degree, their labelling can make their consumers believe that they have a strong connection to the location even though their material geography is very different (Pike 2015). Our research does not reply to the question of why these products were labelled as regional, however, such inflation labelling can drive the second wave of product standardisation and subsequent devaluation of the idea of regional labelling. This kind of standardisation can occur when a unique regional product, which escaped global regulations and requirements of the mass market (first wave of standardisation), is getting standardised again in the mass of similar products whose creation and promotion was supported by regional labelling authorities. In order to legitimate their regional labels and earn finances for their operation, these authorities need to reach a critical mass of regional products just by labelling products which are not typical for a particular region.

On the other hand, there is a question about whether there is a sufficient number of producers in the Ústí Region who could offer such authentic and regional products; its lack might then support the inflation labelling. Such assumption might be based on several factors influencing the supply of regional products in the Ústí Region:

- Tremendous pressure of large or international companies that do not allow new regional products to break through on the market;

- Insufficient business know-how and skills of regional farmers and craftsmen to succeed on the market (related with a previously mentioned factor);

- Retreat of economic branches, or economic activities, that were important for creating authentic regional products in connection with the expulsion of Germans (see the example of wooden decorations - the best assessed product; only two assessed products have a tradition dating back to the pre-war period); and/or

- Business tradition interrupted by socialism (only seven products have a tradition dating back or overlapping the period of socialism).

From this point of view, it would be interesting to apply this method on other regions of Czechia that were not affected by the post-war expulsion of Germans, or regions in other countries not influenced by the socialistic organisation of the economy.

Furthermore, it is necessary to research how the term "regional" is perceived in the context of regional products and labelling authorities. Subsequently, it would be suitable to change its meaning into a form that would ensure regional labelling more sensible to specific regional, social, economic, and cultural circumstances. Such meaning must then be disseminated among various labelling authorities.

For the beginning, representatives of labelling authorities could better consider the economic history of their region and especially its past key economic industries. Such key industries should be defined and labelling authorities should then actively search for corresponding producers who could be then encouraged to participate in regional labelling schemes. From this point of view, it 
can be spoken about to some kind of smart specialization strategies of regional labelling. Such kind of promotion could bring two important results: both rising number of regional products legitimating and financing the activity of labelling authorities and improvement in the regionality degree of labelled products. These two results would then contribute significantly to the rising quality of the given regional label. Moreover, stressing the traditional economic industries might also help to create or strengthen the positive regional image.

Labelling authorities might also better examine the products' biography, especially regarding the regional origin of raw materials. As such, they would become a part of the economic localization endeavour of local stakeholders. In time, when the economic localization is becoming the crucial part of rural development policies, this could really help to legitimate their function, similarly as their contribution to the positive regional image.

\section{Acknowledgement}

The preparation of the article was supported by a grant project "Perception of restructuralized territories in the context of various forms of commodification", funded by Student Grant Competition of the J. E. Purkyně University in Ústí nad Labem.

\section{Academic references}

[1] Allen, P. \& Hinrichs, C. (2007). Buying into "Buy Local": Engagements of United States local food initiatives. In: Maye, D., Holloway, L. \& Kneafsey, M., eds., Alternative food geographies: representation and practice (pp. 255-272). Amsterdam: Elsevier.

[2] Anděl, J., et al. (2000). Geografie Ústeckého kraje. Ústí nad Labem: Univerzita J. E. Purkyně v Ústí nad Labem.

[3] Bauman, Z. (2007). Consuming Life. Cambridge: Polity.

[4] Bourguignon, F., et al. (2002). Making sense of globalization. A Guide to the Economic Issues. [CEPR Policy Paper No. 8]. London: Centre for the Economic Policy Research.

[5] Broumová, L. (2015). Hodnocení stupně regionality regionálních produktư Ústeckého kraje [Bachelor thesis]. Ústí nad Labem: Univerzita J. E. Purkyně v Ústí nad Labem.

[6] Coe, N., Kelly, P. \& Yeung, H. (2013). Economic geography: a contemporary introduction. $2^{\text {nd }}$ edition. Hoboken: Wiley.

[7] Copus, A., Hopkins, J. \& Creaney, R. (2016). The transaction footprints of Scottish food and drink SMEs. European Countryside 8(3), 227-249. DOI: 10.1515/euco-2016-0017.

[8] Fraňková, E. (2012). Ekonomická lokalizace $v$ environmentálních souvislostech aneb Produkce a spotreba zblízka [PhD. Theses]. Brno: Masarykova univerzita.

[9] Gray, J. (2000). The Common Agricultural Policy and the re-invention of the rural in the European Community. Sociologia Ruralis 40(1), 30-52. DOl: 10.1111/1467-9523.00130.

[10] Groote, P., Huigen. P. \& Haartsen, T. (2000). Claiming rural identities. In Haartsen, T., Groote, P. \& Huigen, P., eds., Claiming rural identities: dynamics, contexts, policies (pp. 1-9). Assen: Van Gorcum.

[11] Hall, C. (2006). Introduction: Culinary tourism and regional development: from slow food to slow tourism? Tourism Review International 9(4), 303-305. DOI: $10.3727 / 154427206776330580$.

[12] Hall, C. \& Gössling, S (2016). From food tourism and regional development to food, tourism and regional development: Themes and issues in contemporary foodscapes. In Hall, C. \& Gössling, S., eds., Food tourism and regional development: Networks, products and trajectories (pp. 3-57). Abingdon: Routledge. 
[13] Holmes, J. (2006). Impulses towards a multifunctional transition in rural Australia: Gaps in the research agenda. Journal of Rural Studies 22(2), 142-160. DOI: 10.1016/j.jrurstud.2005.08.006.

[14] Hruška, V. \& Konečný, O. (2014). Prostory venkova. In Matoušek, R. \& Osman, R.: Prostor(y) geografie (pp. 189-211). Praha: Karolinum.

[15] Chalupová, M., Prokop, M. \& Rojík, S. (2016). Regional Food Preference and Awareness of Regional Labels in Vysočina Region (Czech Republic). European Countryside 8(2), 109122. DOI: 10.1515/euco-2016-0009.

[16] Goodman, M. \& Goodman, D. (2009). Alternative food networks. In Kitchin, R. \& Thrift, N., eds., International encyclopedia of human geography (pp. 208-220). Amsterdam: Elsevier.

[17] Ilbery, B. \& Bowler, I. (1998). From agricultural productivism to post-productivism. In Ilbery, B., ed. The geography of rural change (pp. 57-84). Essex: Longmann.

[18] Ilbery, B. \& Kneafsey, M. (1999). Niche Markets and Regional Speciality Food Products in Europe: Towards a Research Agenda. Environment and Planning 31(12), 2207-2222. DOI: $10.1068 / \mathrm{a} 312207$.

[19] Johanisová, N. (2004). Lokální ekonomika v praxi. Sedmá generace 5.

[20] Kapferer, J. N. (2002). Is There Really No Hope for Local Brands? Journal of Brand Management 9(3), 163-170. DOI: 10.1057/palgrave.bm.2540066.

[21] Kárníková, L. (1965). Vývoj obyvatelstva v českých zemích 1754-1914. Praha. Nakladatelství Československé akademie věd.

[22] Kašková, M. (2010). Role systémů značení regionálních produktů $v$ procesu institucionalizace regionů a $v$ jejich rozvoji [Diploma thesis]. Praha: Univerzita Karlova.

[23] Kašková, M. \& Chromý, P. (2014). Regional product labelling as part of the region formation process. The case of Czechia. Acta Universitatis Carolinae Geographica 49(2), 87-98.

[24] Kašková, M., Kučera, Z., Chromý, P. (2016). Místo a značka: place branding a problémy jeho konceptualizace. Informace ČGS 35(2), 1-16.

[25] Klánová, E. (2013). Značky kvality fungují, pokud jim zákazník věří: Prioritu má zkušenost s výrobkem. Retail Info Plus 3(5), 14-15.

[26] Koutský, J. (2011). Staré průmyslové regiony, vývojové tendence - možnosti rozvoje. Ústí nad Labem: Univerzita J. E. Purkyně v Ústí nad Labem.

[27] Kučerová, S. R., Kučera, Z., Novotná, K. \& Šifta, M. (2016). Die Veränderung der Identität von Regionen in tschechischen Geographieschulbüchern vor und nach 1989. In Matthes, E. \& Schütze, S., eds., „1989“ und Bildungsmedien (pp. 109-123). Bad Heilbrunn: Verlag Julius Klinkhardt.

[28] Mackay, M., Perkins, H. C. \& Espiner, S. (2009). The study of rural change from a social scientific perspective: a literature review and annotated bibliography. Lincoln: Lincoln University.

[29] Mackinnon, D. \& Cumbers, A. (2007). An introduction to economic geography: globalization, uneven development and place. Harlow: Pearson.

[30] Mareš, J. (1980). Průmyslové regiony ČSR. Praha: Academia.

[31] McCarthy, J. (2005). Rural geography: multifunctional rural geographies reactionary or radical? Progress in Human Geography 29(6), 773-782. DOI: 10.1191/0309132505ph584pr.

[32] Moseley, M. J. (2003). Rural development: principles and practice. Thousand Oaks: SAGE.

[33] Olšová, P. \& Jánská, M. (2016). Location of super and hypermarkets in the city of Ústí nad Labem. GeoScape, 10(1), 16-24. DOI: 10.1515/geosc-2016-0002. 
[34] Paasi, A. (2003). Region and place: regional identity in question. Progress in Human Geography 27(4), 475-485. DOI: 10.1191/0309132503ph439pr.

[35] Parrott, N., Wilson, N. \& Murdoch, J. (2002). Spatializing Quality: Regional Protection and the Alternative Geography of Food. European Urban and Regional Studies 9(3), 241-261. DOI: $10.1177 / 0967642002009003878$.

[36] Pike, A. (2015). Origination: The Geographies of Brands and Branding, Chichester: Wiley Blackwell.

[37] Purš, J. (1980). Changes in the spatial organization of industry in Bohemia at the threshold of the industrial revolution. Historická geografie 19, 247-282.

[38] Ray, C. (1998). Culture, Intellectual Property and Territorial Rural Development. Sociologia Ruralis. 38(1), 3-20. DOI: 10.1111/1467-9523.00060.

[39] Ray, C. (2006). Neo-Endogenous Rural Development in the EU. In Cloke, P., Marsden, T. \& Mooney, P., eds., Handbook of rural studies (pp. 278-292). London. SAGE.

[40] Renting, H., Marsden, T. \& Banks, J. (2003). Understanding alternative food networks: exploring the role of short food supply chains in rural development. Environment and Planning A 35, 3, 393-411. DOI: 10.1068/a3510.

[41] Schermer, M. (2015). From „Food from Nowhere“ to „Food from Here“: changing producerconsumer relations in Austria. Agricultural Human Values 32(1), 121-132. DOI: 10.1007/s10460-014-9529-z.

[42] Short, B. (2006). Idyllic ruralities. In: Cloke, P., Marsden, T. \& Mooney, P., eds., Handbook of rural studies (pp. 133-148). London. SAGE.

[43] Spilková, J. \& Fialová, D. (2016). Produktové značky: kdo značí, má za tři? In Spilková, J., ed., Alternativní potravinové sítě: česká cesta (pp. 143-159). Praha: Karolinum.

[44] Spilková, J. \& Perlín, R. (2013). Farmers' markets in Czechia: risks and possibilities. Journal of Rural Studies 32, 220-229. DOI: 10.1016/j.jrurstud.2013.07.001.

[45] Van Der Ploeg, J., Renting, H., Brunori, G., Knickel, K., Mannion, J., Marsden, T., de Roest, K., Sevilla-Guzmán, E. \& Ventura, F. (2000). Rural development: from practices and policies towards theory. Sociologia Ruralis 40(4), 391-408. DOI: 10.1111/1467-9523.00156.

[46] Winter, M. (2003). Geographies of food: agro-food geographies - making reconnections. Progress in Human Geography 27(4), 505-513. DOI: 10.1191/0309132503ph446pr.

[47] Woods, M. (2005). Rural geography: Processes, Responses and Experiences in Rural Restructuring. London: SAGE.

[48] Woods, M. (2011). Rural. London: Routledge.

Other sources

[49] Asociace regionálních značek (Association of Regional Brands), (2016). Regionální produkty: $O$ asociaci (Regional products: About the Association) [online]. [Accessed 2016-02-03]. Retrieved from: http://www.regionalni-znacky.cz/arz/cs/o-nas/.

[50] Česká akademie věd a umění (1935). Atlas republiky Československé (Atlas of the Czechoslovak Republic). Praha.

[51] Český statistický úrad (Czech Statistical Office), (2014). Charakteristika kraje [online]. [Accessed 2015-02-26]. Retrieved from: https://www.czso.cz/csu/xu/charakteristika_kraje.

[52] Kašková, M. (2014). Značení regionálních produktů v Česku: očekávání a realita [Accessed 2016-12-10]. Výzkumné centrum historické geografie. Retrieved from: http://geography.cz/wp-content/uploads/2014/02/4_Kaskova_Venkov2014.pdf. 
[53] Kučera, Z. et al. (2014). Identity českého Severozápadu. Univerzita J. E. Purkyně v Ústí nad Labem, Univerzita Karlova v Praze [online]. [Accessed 2016-12-10]. Retrieved from: www.academia.edu/6989806/Identity_\%C4\%8Desk\%C3\%A9ho_Severoz\%C3\%A1pad.

[54] Messely, L., Dessein, J. \& Lauwers, L. (2009). Branding regional identity as a driver for rural development. Belgrad, Serbia.

[55] MPSV (2017). Integrovaný portál MPSV: Měsíčni statistika nezaměstnanosti (Integrated website of the MSA: Monthly unemployment statistics) [online]. [Accessed 2017-29-08]. Retrieved from: https://portal.mpsv.cz/sz/stat/nz/mes.

[56] Ústecký kraj (2016). Katalog remesIné výroby Ústeckého kraje. Ústí nad Labem: Krajský Úřad Ústeckého kraje.

[57] Woods, M. (2009). Developing Europe's rural regions in the era of globalisation: literature review and conceptual framework [online]. [Accessed 2010-12-13]. Retrieved from: http://www.derreg.eu/deliverables_publications/derreg\%20d5.1\%20conceptual\%20framewo rk.pdf.

[58] UNWTO, ETC (2009). Handbook of Tourism Destination Branding. Madrid: WTO. 